(C) Yelins'ka A.M., Kostenko V.O.

UDC 616.314.17+611.018.2:599.323.4

DOI https://doi.org/10.31718/mep.2019.23.5-6.07

\title{
SYNERGISTIC EFFECT OF QUERCETIN AND EPIGALLOCATECHIN-3-GALLATE AS AGENTS TO PREVENT CONNECTIVE TISSUE DISINTEGRATION IN THE PERIODONTIUM OF RATS UNDER SYSTEMIC AND LOCAL ADMINISTRATION OF LIPOPOLISACCHARIDE OF SALMONELLA TYPHI*
}

\author{
Yelins'ka A.M., Kostenko V.O.
}

Ukrainian Medical Stomatological Academy, Poltava, Ukraine

Метою цього дослідження було дослідження поєднаної дії водорозчинної форми кверцетину та епігаллокатехін-3галлату (EGCG) на біохімічні маркери деполімеризації органічного матриксу пародонту при системному та місцевому введенні ліпополісахариду S. tурhі (ЛПС). Дослідження проводили на 30 білих щурах лінії Вістар масою 180220 г, розподілених на 5 груп: 1-ша включала інтактних тварин, 2-га - тварин після комбінованого системного і місцевого введення ЛПС, 3-а та 4-а групи -щурів, яким вводили відповідно ін'єкції водорозчинної форми кверцетину (10 мг/кг) та EGCG (21,1 мг/кг) 3 рази на тиждень, починаючи з 30-го дня системного введення ЛПС, у 5-ій групі тварини зазнавали поєднане введення воднорозчинної форми кверцетину і EGCG. Було виявлено, що спільна дія кверцетину та EGCG при системному і місцевому введенні ЛПС супроводжується зниженням концентрації Nацетилнейрамінової кислоти (NANA) на 31,8 і 32,8\% відповідно в м'яких тканинах пародонту порівняно зі значеннями тварин з окремим введенням кверцетину і EGCG за умов експерименту. Проте не було виявлено жодних відмінностей між групами, що піддавалися поєднаній або окремій дії цих агентів при оцінці вмісту вільного гідроксипроліну (FHP) та глікозаміногліканів (GAGs) у м'яких тканинах пародонта. У той же час комбіноване застосування кверцетину і EGCG за умов експерименту призводило до зниження вмісту FHP в альвеолярній кістці на 24,5 i 20,2\% відповідно порівняно зі значеннями тварин, які зазнавали окрему дію кверцетину та ЕGCG. Концентрація NANA була знижена на 35.0 і 41,3\% відповідно. Таким чином, спільне введення водорозчинної форми кверцетину i EGCG при системному і місцевому введенні ЛПС S. tурһі виявилося більш ефективним засобом для запобігання i корекції дезінтеграції сполучної тканини пародонта, ніж це відбувається при окремому введенні кожного з поліфенолів.

Ключові слова: кверцетин, епігаллокатехін-3-галат, ліпополісахарид, дезінтеграція сполучної тканини, пародонт.

The aim of the present study was to investigate the co-effect produced by water-soluble form of quercetin and epigallocatechin-3-gallate (EGCG) on biochemical markers of periodontal organic matrix depolimerization under systemic administration and local application of S. typhi lipopolisaccharide (LPS). The studies were conducted on 30 white rats of the Wistar line weighing 180-220 g, divided into 5 groups: the $1^{\text {st }}$ included intact animals, the $2^{\text {nd }}$ was made up of animals after the combined systemic and local LPS administration, the $3^{\text {rd }}$ and $4^{\text {th }}$ groups included animals, which were being given injections with water-soluble form of quercetin $(10 \mathrm{mg} / \mathrm{kg})$ and EGCG $(21.1 \mathrm{mg} / \mathrm{kg})$ respectively 3 times a week, starting on the $30^{\text {th }}$ day of the systemic LPS administration, and the $5^{\text {th }}$ group involved rats, which were injected with coadministered water-soluble form of quercetin and EGCG. It has been found out that the co-effect produced by quercetin and EGCG under systemic and local LPS administration is accompanied with reduced concentration of N-acetylneuraminic acid (NANA) by 31.8 and $32.8 \%$ respectively in the soft periodontal tissues compared with values for the animals received separate quercetin and EGCG during the experiment. However, no differences have been detected between the groups exposed to combined or separate action of the above mentioned agents in the experiment when assessing free hydroxyproline (FHP) and glycosaminoglycans (GAGs) content in the soft tissues of periodontium. At the same time combined use of quercetin and EGCG under experimental conditions led to the decrease in the FHP content in the alveolar bone by 24.5 and $20.2 \%$ respectively compared with values for the animals received separate quercetin and EGCG. NANA concentration was reduced by 35.0 and $41.3 \%$ respectively. Thus, the co-administration of water-soluble form of quercetin and epigallocatechin-3-gallate under systemic and local introducing of $S$. typhi lipopolysaccharide has been proven to be more effective means for preventing and correcting periodontal connective tissue disruption than this occurs at separate administration of each of the polyphenols.

Key words: quercetin, epigallocatechin-3-gallate, lipopolisaccharide, connective tissues disintegration, periodontium.

\section{Introduction}

Epigallocatechin-3-gallate (EGCG) is a polyphenol found in green tea (Camellia sinensis), that promotes the activation of Nrf2 transcription factor (Nuclear Factor Erythroid 2-Related Factor 2) due to proteolysis of an inhibitory protein Keap1 [4]. This pathway enhances antioxidant activity of a number of enzymes through cisacting enhancer sequence, known as antioxidant re- sponse element (ARE) [10, 13]. In our previous reports we have demonstrated that the administration of EGCG under modeled systemic inflammatory response (SIR) is an effective means of preventing and correcting the disruption of periodontium connective tissue in rats: it reduces collagenolysis and depolymerization of proteoglycans and glycoproteins [17]. A particular role of ARE is determined by the fact that transcriptional nuclear factors

\footnotetext{
* To cite this english version: Yelins'ka A.M., Kostenko V.O. Synergistic effect of quercetin and epigallocatechin-3-gallate as agents to prevent connective tissue disintegration in the periodontium of rats under systemic and local administration of lipopolisaccharide of salmonella typhi. // The Medical and ecological problems. - 2019. - Vol 23, № 5-6. - P. 42-44.
} 
KB (NF-KB) and activator protein 1 (AP-1) activation depends on its activity [13]. Nowadays, the ability of quercetin to influence on the activity of enzymes involved in the degradation of phospholipids (phospholipase, lipoxygenase, cyclooxygenase), and to block oxidative stress-dependent connective tissue disruption has already been proven [5]. There is evidence suggesting quercetin ability to activate the Nrf2-dependent $\mathrm{HO}-1$ pathway and suppress ubiquitin-dependent proteolysis of NF-kB with an inhibitory protein IKB, which impairs the degradation of the latter under the proteasome action [3]. This creates the prerequisites for eliminating the possibility of NF-kB-dependent expression of numerous genes, a significant number of which encodes hystolitic matrix metalloproteinases (MMP), proinflammatory cytokines, inducible NO-synthase, etc [6] Recently, it has been reported that an administration of NF-KB inhibitors is accompanied by an increase in periodontal collagenprotective activity of L-arginine [8] However, the combined use of EGCG and quercetin for prevention and correction of connective tissue disintegration in periodontium of rats under systemic and local pathogens action is still remaining unclear.

The aim of the present study was to investigate the co-effect produced by quercetin and EGCG on biochemical markers of periodontal organic matrix depolimerization under systemic and local administration of $S$. typhi lipopolisaccharide (LPS).

\section{Materials and methods}

The studies were conducted on 30 white rats of the Wistar line weighing $180-220 \mathrm{~g}$, divided into 5 groups: the $1^{\text {st }}$ included intact animals, the $2^{\text {nd }}$ was made up of animals after the combined systemic and local LPS administration, the $3^{\text {rd }}$ and $4^{\text {th }}$ groups included animals, which were given injections with water-soluble form of quercetin and EGCG respectively, and the $5^{\text {th }}$ group involved rats, which were injected with co-administered water-soluble form of quercetin and EGCG. For systemic administration, S. typhi LPS (pyrogenalum, "Medgamal", Russia) was injected intraperitoneally in a dose that stimulated rise in temperature by $1.5^{\circ} \mathrm{C}$ according to the scheme
[19]: during the first week, 4 minimum pyrogenic doses (MPD) of $0.4 \mu \mathrm{g} / \mathrm{kg}$ of body weight were given 3 times a week. During the following 7 weeks of the experiment, rats were given 4 MPD / kg of body weight once a week. For local administration, S. typhi LPS was introduced once in as dose of $1 \mu \mathrm{g} / \mathrm{kg}$, equally divided into four injections into the gum at the level of the second molars 7 days prior to the decapitation (acute gingivitis model). Water-soluble form of quercetin (corvitin, "Borshchahivskiy CPP", Ukraine) was administered intraperitoneally in a daily dose of $10 \mathrm{mg} / \mathrm{kg}$ recalculated for quercetin [5], and EGCG (Sigma-Aldrich, Inc., USA) was administered in a dose of $21.1 \mathrm{mg} / \mathrm{kg}$ [17] 3 times a week, starting on the $30^{\text {th }}$ day of the systemic LPS administration.

The research was guided by the principles of biomedical ethics. The animals were decapitated under ethereal anesthesia. The level of collagenolysis was assessed by the content of free hydroxyproline (FHP) [12]. The process of depolymerization of proteoglycans and sialoglycoproteins was evaluated by determining their monomers - glycosaminoglycans (GAGs) [11] and Nacetylneuraminic acid (NANA) [9] respectively.

The findings obtained were statistically processed. To verify the normality distribution, the calculation of the Shapiro-Wilk criterion was applied. If they corresponded to the normal distribution, then the Student's t-test was used to compare independent samples. When the results ranges were not subject to normal distribution, statistical processing was performed using a nonparametric method, the Mann-Whitney test. Statistical calculations were performed using the "StatisticSoft 6.0" program.

\section{Results and discussion}

Systemic and local LPS co-administration led to significant changes in the biochemical markers of periodontal organic matrix destruction (Table 1). Thus, the FHP and GAGs content went up by 2.25 times, NANA - by 2.28 times in the soft periodontal tissues. Concentration of these compounds in the calcified components of periodontium (alveolar bone) increased as well: FHP - by 2.45 times, GAGs - by 2.25 times, NANA - by 3.55 times. disruption under systemic and local administration of $S$. typhi lipopolysaccharide $(M+m, n=35)$

\begin{tabular}{|c|c|c|c|c|c|c|}
\hline \multirow{2}{*}{ Groups of the animals } & \multicolumn{3}{|c|}{$\begin{array}{c}\text { Soft components } \\
\text { (gingiva and periodontal ligament) }\end{array}$} & \multicolumn{3}{|c|}{$\begin{array}{l}\text { Calcified components } \\
\text { (alveolar bone) }\end{array}$} \\
\hline & $\begin{array}{l}\mathrm{FHP}, \\
\mu \mathrm{mol} / \mathrm{g}\end{array}$ & GAGs, $\mu \mathrm{mol} / \mathrm{g}$ & NANA, $\mu \mathrm{mol} / \mathrm{g}$ & $\begin{array}{l}\mathrm{FHP}, \\
\mu \mathrm{mol} / \mathrm{g}\end{array}$ & $\begin{array}{l}\text { GAGs, } \\
\mu \mathrm{mol} / \mathrm{g}\end{array}$ & NANA, $\mu \mathrm{mol} / \mathrm{g}$ \\
\hline Control group I (intact animals) & $\begin{array}{c}4.08 \\
\pm 0.48\end{array}$ & $\begin{array}{r}1.93 \\
\pm 0.34 \\
\end{array}$ & $\begin{array}{r}4.56 \\
\pm 0.17\end{array}$ & $\begin{array}{r}3.06 \\
\pm 0.28 \\
\end{array}$ & $\begin{array}{c}1.70 \\
\pm 0.30\end{array}$ & $\begin{array}{c}2.00 \\
\pm 0.35\end{array}$ \\
\hline \begin{tabular}{|l|} 
Control group II (combined sys- \\
temic and local LPS introduction)
\end{tabular} & $\begin{array}{c}9.20 \\
\pm 0.23\end{array}$ & $\begin{array}{c}4.36 \\
\pm 0.17 \text { * } \\
\end{array}$ & $\begin{array}{c}10.4 \\
\pm 0.81 * \\
\end{array}$ & $\begin{array}{c}7.51 \\
\pm 0.24\end{array}$ & $\begin{array}{c}3.84 \\
\pm 0.21 \\
\end{array}$ & $\begin{array}{c}7.10 \\
\pm 0.24 \text { * } \\
\end{array}$ \\
\hline + water-soluble form of quercetin & $\begin{array}{c}5.31 \\
\pm 0.42 \text { ** }\end{array}$ & $\begin{array}{c}2.59 \\
\pm 0.40 \text { ** }\end{array}$ & $\begin{array}{c}6.22 \\
\pm 0.19 * / * * \\
\end{array}$ & $\begin{array}{c}3.92 \\
\pm 0.12^{* / * *} \\
\end{array}$ & $\begin{array}{c}2.22 \\
\pm 0.18^{* *}\end{array}$ & $\begin{array}{c}3.23 \\
\pm 0.42^{* *}\end{array}$ \\
\hline+ EGCG & $\begin{array}{c}5.16 \\
\pm 0.44 \text { ** }\end{array}$ & $\begin{array}{c}2.27 \\
\pm 0.30 \text { ** }\end{array}$ & $\begin{array}{c}6.31 \\
\pm 0.26 * / * * \\
\end{array}$ & $\begin{array}{c}3.71 \\
\pm 0.24 \text { ** }\end{array}$ & $\begin{array}{c}1.99 \\
\pm 0.13^{* *}\end{array}$ & $\begin{array}{c}3.58 \\
\pm 0.40^{* * *}\end{array}$ \\
\hline $\begin{array}{l}\text { + water-soluble form of quercetin } \\
\text { + EGCG }\end{array}$ & $\begin{array}{c}4.04 \\
\pm 0.42^{* *}\end{array}$ & $\begin{array}{c}1.93 \\
\pm 0.27 \text { ** }\end{array}$ & $\begin{array}{c}4.24 \\
\pm 0.29 \\
\star * * / * * / \\
\star \star \star * \star \\
\end{array}$ & $\begin{array}{c}2.96 \\
\pm 0.13 \\
* \star / * * * \\
* * * *\end{array}$ & $\begin{array}{c}1.70 \\
\pm 0.28 \text { ** }\end{array}$ & $\begin{array}{c}2.10 \\
\pm 0.19 \\
* * / * * * / \\
\star \star * * *\end{array}$ \\
\hline
\end{tabular}

Note: * $p<0.05$ compared with values in the control group I (intact rats);

${ }^{* *}$ with control group II; ${ }^{* * *}$ with animals received quercetin only under experiment;

**** $p<0.05$ with rats received EGCG only under experiment.

Resent studies have demonstrated the activation of NF-KB and AP-1 enhances MMP-13 (collagenase-3) gene expression [2]. Introduction of an inhibitor of the nuclear translocation of NF-kB 4-methyl-N-(3-phenylpropyl) 
benzene-1,2-diamine in systemic inflammatory response under experimental metabolic syndrome reduces the amount of FHP and GAGs in periodontal tissues [7].

It has been found that the separate administration of both quercetin and EGCG reduces the concentration of FHP by 42.3 and $43.9 \%$, the content of GAGs by 40.6 and $47.9 \%$, and NANA content by 40.2 and $39.3 \%$ respectively in the soft periodontal tissues compared with the relevant findings in the $2^{\text {nd }}$ group of the test animals. In this experimental model, the concentration of these compounds in the calcified components of periodontium (alveolar bone) lowered as well: FHP - by 47.8 and $50.6 \%$, GAGs - by 42.2 and $48.2 \%$, NANA - by 54.5 and $49.6 \%$ respectively compared with the relevant findings in the $2^{\text {nd }}$ group of the animals.

Co-effect produced by quercetin and EGCG under systemic and local LPS administration demonstrates the reduced NANA concentration by 31.8 and $32.8 \%$ respectively in the soft periodontal tissues compared with values for the animals received separate quercetin and EGCG during the experiment. However, no differences were found out between the groups exposed to either combined or separate action of the above mentioned agents in the experiment when assessing FHP and GAGs content in the soft tissues of periodontium.

At the same time the combined use of quercetin and EGCG under experimental condition led to decrease in the FHP content in the alveolar bone by 24.5 and $20.2 \%$ respectively compared with values for the animals received separate quercetin and EGCG. NANA concentration was reduced by 35.0 and $41.3 \%$ respectively. No differences were found between the groups exposed to either combined or separate action of the agents in the experiment when assessing GAGs content in the calcified components of periodontium.

The results obtained have demonstrated the synergic effect produced by water-soluble form of quercetin and EGCG on the correction of connective tissue disruption in the periodontal tissues.

Resent studies have shown the potential of Keap1 / Nrf2 / ARE system to control other redox-sensitive elements, including NF-KB i AP-1 [14]. We have also found out the activation of NF-KB and AP-1 is an important component in the mechanism of free radical injury and extracellular matrix destruction in the periodontal tissues during systemic inflammatory response $[1,7,15,16]$.

Co-administration of water-soluble form of quercetin and EGCG enables to limit NF-KB and AP-1-dependent mechanisms of periodontal disintegration more effectively as well as to enhance periodontium resistance associated with ARE-dependent gene expression.

Thus, the co-administration of water-soluble form of quercetin and epigallocatechin-3-gallate under systemic and local introduction of $S$. typhi lipopolysaccharide has been proven to be more effective means for preventing and correcting periodontal connective tissue disintegration than this occurs at separate administration of each of the polyphenols.

\section{References}

1. Ambili R, Janam P.A critique on nuclear factor-kappa $B$ and signal transducer and activator of transcription 3: The key transcription factors in periodontal pathogenesis. J Indian Soc Periodontol. 2017 Sep-Oct;21(5): 350-6.
2. Han Z, Boyle DL, Manning AM, Firestein GS AP-1 and NFkappaB regulation in rheumatoid arthritis and murine collagen-induced arthritis. Autoimmunity. 1998;28(4):197-208.

3. Kang $\mathrm{CH}$, Choi $\mathrm{YH}$, Moon $\mathrm{SK}$ et al. Quercetin inhibits lipopolysaccharide-induced nitric oxide production in BV2 microglial cells by suppressing the NF-KB pathway and activating the Nrf2-dependent HO-1 pathway. Int Immunopharmacol. 2013 Nov; 17(3):808-13.

4. Kanlaya R, Khamchun S, Kapincharanon C, Thongboonkerd $V$ Protective effect of epigallocatechin-3-gallate (EGCG) via Nrf2 pathway against oxalate-induced epithelial mesenchymal transition (EMT) of renal tubular cells. Sci Rep. 2016 Jul 25;6:30233.

5. Khmil' DO, Kostenko VO Combined effect of L-arginine and water-soluble form of quercetin on markers of oxidative-nitrosative stress in skin of rats exposed to excessive sodium nitrate. Fiziol Zh. 2017; 63(6):53-9. (In Ukrainian).

6. Liu X, Lin R, Zhao B, Guan R, Li T, Jin R. Correlation between oxidative stress and the NF-KB signaling pathway in the pulmonary tissues of obese asthmatic mice. Mol Med Rep. 2016 Feb;13(2):1127-34.

7. Ljashenko LI, Denisenko SV, Kostenko VA Role of transcription nuclear factor $\mathrm{KB}$ in mechanisms of free radical processes impairment and connective tissue disorganization in periodontium under modeled metabolic syndrome. Aktual'ni problemy suchasnoyi medytsyny: Visn Ukr med stomatol akad. 2014; 14(1):97-100. [In Ukrainian].

8. Lyashenko LI, Kostenko VO NF-kB-mediated influence of NO-synthases on free radical processes in the periodontal tissues under modeled metabolic syndrome. Aktualni problemy suchasnoyi medytsyny: Visn Ukr med stomatol akad. 2014; 14(2):140-3. [In Ukrainian].

9. Methods of clinical and experimental research in medicine (Ed. IP Kaidashev). - Poltava; 2003. 320 p. [In Ukrainian].

10. Ma Q Role of Nrf2 in oxidative stress and toxicity. Annu Rev Pharmacol Toxicol. 2013;53:401-26.

11. Sharayev PN Method for the determination of glycosaminoglycans in biological fluids. Lab delo. 1987;(5):530-2. [In Russian].

12. Tetyanets SS. Method for the determination of free hydroxyproline in serum. Lab delo. 1985;(1):61-6. [In Russian].

13. Tonelli C, Chio IIC, Tuveson DA Transcriptional Regulation by Nrf2. Antioxid Redox Signal. 2018 Dec 10;29(17):1727-45.

14. Wardyn JD, Ponsford AH, Sanderson CM Dissecting molecular cross-talk between Nrf2 and NF-KB response pathways. Biochem Soc Trans. 2015 Aug;43(4):621-6.

15. Yelins'ka AM, Akimov OYe, Kostenko VO Role of AP-1 transcriptional factor in development of oxidative and nitrosative stress in periodontal tissues during systemic inflammatory response. Ukr Biochim J. 2019;91(1):80-5.

16. Yelins'ka AM, Kostenko VO Influence of AP-1 transcription factor inhibitors on the protein depolimerization in periodontal connective tissue of rats under systemic inflammatory response. Aktual'ni problemy suchasnoyi medytsyny: Visn Ukr med stomatol akad. 2018;18(2):335-9. [In Ukrainian].

17. Yelins'ka AM, Shvaykovs'ka OO, Kostenko VO Epigallocatechin-3-gallate prevents disruption of connective tissue in periodontium and salivary glands of rats during systemic inflammation. Wiad Lek. 2018;71(4):869-73.

18. Yelins'ka AM, Shvaykovs'ka OO, Kostenko VO Influence of ammonium pyrrolidine dithiocarbamate on production of reactive oxygen and nitrogen species in tissues of periodontium and salivary glands of rats exposed to systemic administration of Salmonella typhi lipopolisaccharide. Fiziol Zh. 2018;64(5):63-9. [In Ukrainian].

19. Yelins'ka AM, Shvaykovs'ka OO, Kostenko VO Sources of production of reactive oxygen and nitrogen species in tissues of periodontium and salivary glands of rats under modeled systemic inflammation. Probl ekol med. 2017;21(3-4):51-4.

Матеріал надійшов до редакції 23.08.2019. 